\title{
A CIDADE DO ANÔNIMO: EXPERIMENTAÇÕES ÉTICAS
}

\author{
THE CITY OF ANONYMITY: ETHICAL EXPERIMENTATIONS
}

LA CIUDAD DEL ANÓNIMO: EXPERIMENTACIONES ÉTICAS

\author{
Luis Antonio dos Santos Baptista* \\ Mario Cesar Carvalho de Moura Candido ${ }^{* *}$ \\ Raphael Ferreira de Avila**
}

\begin{abstract}
RESUMO
Deseja-se, nesta escrita, pensar o poder da máscara e do anonimato como formas de experimentação ética e política. Para tanto, é preciso se permitir contagiar pela intensidade dos paradoxos das lutas sociais que hoje habitam as ruas da cidade contemporânea. Ensaia-se, neste artigo, a tentativa de fazer do anônimo uma ferramenta conceitual que forneça o oxigênio necessário para continuarmos atentos às barbáries da atualidade, distanciando-nos da dinâmica de uma subjetividade privatizada, assim como das amarras de um coletivo identitário. Os autores consultados no texto formulam a hipótese na qual o anônimo seria uma modalidade de resistência. Qual resistência? Qual seria a aposta ética presente no anonimato? Esses exercícios e experimentações apontam para conclusóes abertas que visam a ampliar e tornar mais complexa a capilaridade da violência de Estado, assim como as inesgotáveis formas de combatê-la.
\end{abstract}

Palavras-chave: Cidade. Anonimato. Ética.

\section{ABSTRACT}

This article intends to explore the subjects of masks and anonymity as possible ways to engage in ethical and political experimentations. For that matter it is important to let ourselves be affected by the intensity of paradoxes that inhabit the city's streets and social struggles associated with them. The essay treats anonymity as a conceptual tool that could bring fresh thinking and air to the constant vigil against modern oppression, keeping us away from a private subjectivity as well from the constraints found in identitarian collectives. The investigation puts anonymity in the realm of resistance: which kind of resistance? What forms of expression could put

\footnotetext{
*Doutor em Psicologia pela Universidade de São Paulo (USP), professor titular no Instituto de Psicologia e no Programa de PósGraduação em Psicologia da Universidade Federal Fluminense (UFF), professor no Programa de Pós-Graduação em Psicologia Social e Institucional da Universidade Federal do Espírito Santo (UFES). E-mail: baptista509@gmail.com.

** Doutorando em Psicologia pela UFF, mestre em Psicologia Institucional pela UFES. E-mail: mariocesar.candido@gmail.com.

"** Doutorando em Psicologia pela UFF, mestre em Psicologia pela Universidade Federal Rural do Rio de Janeiro (UFRRJ), professor na Universidade Estácio de Sá (Unesa-RJ). E-mail: raphaelfdeavila@gmail.com.
} 
it in relation to politics and ethics? Those questions are put into open perspectives that could help address the problems of State violence and the various ways to fight it.

Keywords: City. Anonymity. Ethics.

\section{RESUMEN}

Lo que se intenta con esta escrita es pensar el poder de una máscara y del anonimato como maneras de experimentación ética y política. Para eso es necesario permitir un contagio por la intensidad de las paradojas presentes en las luchas sociales que habitan las calles de la ciudad contemporánea. Intentamos pensar el anónimo como herramienta conceptual que pueda proveernos de aire y fuerza para seguirnos atentos a las barbaries de la actualidad, alejándonos de una subjetividad privatizada y de las restricciones de un colectivo identitario. Los autores utilizados formulan la hipótesis de que el anónimo sería una modalidad de resistencia. ¿Cuál resistencia? ¿Cuál sería la apuesta ética presente en el anonimato? Estos ejercicios y experimentaciones llevan a conclusiones abiertas que pueden ampliar y hacer más compleja la capilaridad de la violencia de Estado y las maneras de enfrentarla.

Palabras clave: Ciudad. Anonimato. Ética.

\section{PRÓlOGO}

$\mathrm{R}$

ostos cobertos, outros não, participam das manifestações urbanas na atualidade. Diferentes apelos, palavras de ordem ocupam as calçadas e - deixam atônitos os que almejam reencontrar a rebeldia de outrora. A face não se deixa ver, e nessa recusa, a cidade é solidária quando se exime de ser apenas palco, cenário, pavimento para circulação. Muitos exibem a face, alguns, conectados ao que a urbe oferece como experimentação, escondem-na e revelam um inaudito rosto. Atordoados ficam os observadores quando não conseguem explicar a singularidade da massa ruidosa movimentando-se como uma chama. Participantes usam máscaras, desdenham uma liderança que os conduza, mas um ponto em comum os une: formulam seus desejos no anonimato. Outro ponto os liga: são usuários da cidade opaca para os limites do olhar ancorado na visibilidade. São manifestantes que exploram a desconfortável invisibilidade da urbe: a de múltiplas e inconclusas faces, a que corrói tempos e espaços da memória dócil dos monumentos, a que dilacera ideias perenes alheias à fuligem das ruas gastas por passagens. Percorrem ruas, escondem o rosto, queimam objetos, recusam queimar, cantam, lutam, desejam. Gestos são modulaçôes 
como labaredas singulares, informes e fugazes na contramão da rigidez do corpo do soldado. A cidade os insufla quando destrói e cria como fogo.

Em algumas manifestações, o rosto é exibido como marca insolúvel. Nessas, os participantes marcham orgulhosos, guiados por seus condutores, líderes ou pastores. Ao exibir a nitidez da face ressaltam a identidade do militante, assim como a do inimigo. No cortejo orgulhoso que esse tipo de manifestação ostenta, a cidade resume-se a ser $o$ assentamento funcional para a exibição do triunfo de uma ideia. O anonimato se torna um adjetivo indesejável. Soldados, irmãos, uma massa uniforme refuta, com veemência, a opacidade de um rosto.

Em outras manifestações, militantes soldados e mascarados misturamse; bandeiras, assim como sua recusa, invadem avenidas; líderes, ao lado da contestação da liderança, irrompem sobre o solo. Anônimos de várias nuances juntam-se aos manifestantes ancorados na clareza do coletivo homogêneo. A cidade, quando refuta ser palco da massa desejante, mistura-se a ela e anuncia a potência dos paradoxos a dissipar a lassidão do pensamento. Os poderes "na" rua entrelaçam-se aos poderes "da" rua, e nada permanece estável, harmônico, concluso. O pano a esconder o que existe abaixo dos olhos ganha o estranhamento necessário para manter a cidade tensa e viva. Pelo estranhamento, o anônimo escapa das amarras do senso comum, do reino da opinião, da moral. Qual sentido teria o anonimato que emerge do asfalto para outros territórios onde embates ainda não se sucederam?

Deseja-se, nesta escrita pensar o poder de uma máscara. $\mathrm{O}$ que esse artefato promove para pensarmos as lutas da atualidade: as que produzem a diferença em cárceres identitários assim como as que os problematizam, ao afirmarem a resistência do anonimato. Manifestações da atualidade não compõem o objeto de nosso estudo. Fomos contagiados e provocados pela fúria dos paradoxos das ruas. Ensaia-se, na escrita, a tentativa de fazer do anônimo uma ferramenta conceitual que forneça o oxigênio necessário para continuarmos atentos às barbáries da atualidade. Os autores utilizados no texto formulam a hipótese de que o anônimo seria uma modalidade de resistência. Qual resistência? O que se afirmaria por detrás de uma máscara? Qual a aposta ética que o anonimato sustenta? 


\section{O ANÔNIMO}

O cortejo mascarado chamou a atenção do filósofo francês. Na terça-feira gorda do carnaval, foliōes desfilavam entre os olhos curiosos dos espectadores da cidade suíça ${ }^{1}$. No bloco carnavalesco, percebia-se uma miscelânea particular que congregava homens, mulheres, crianças ornadas por fantasias e máscaras. O desfile atravessava os portões do velho hospício, percorrendo as ruas de Munsterlingen. Travestidos de Charlie Chaplin, Maurice Chevalier e de outros artistas célebres, comemoravam a folia momesca. Segundo Jean-François Bert, outras modalidades de fantasias eram utilizadas:

A figura do oriental com seu elefante, da sereia e do espadachim, e da coquete no seu estilo démodé, do palhaço com seu chapéu descombinado e, talvez, principalmente, do louco, que, desde a Idade Média, desfila com adereços singulares, entre os quais o cetro, as orelhas de burro e os guizos (Bert \& Verdeaux, 2017, p. 38).

O rosto do folião, nesse dia, não se deixava ver: pacientes, médicos, enfermeiros, o diretor do hospital, citadinos comuns transformavam-se em anônimos por algumas horas. Mascarados perdiam o nome, a função hierárquica no manicômio assim como na vida cotidiana local. Um ambíguo anonimato afirmava-se na impossibilidade do reconhecimento da identidade do carnavalesco, porém fornecia uma pista precisa: o cortejo iniciava o trajeto no hospício. Pacientes e citadinos desfilavam irreconhecíveis no ruidoso cortejo realizado todos os anos. O bloco de Munsterlingen exibia o qualquer um, o ninguém, o inclassificável atrás da máscara e, simultaneamente, o provável perigo, ou mistério, alojado na imperceptível existência da loucura. O anonimato confortável, ou arriscado, circulava pelas ruas, promovendo peculiares paradoxos. A máscara escondia e revelava, seduzia e repelia, aturdia e alegrava no único dia do ano em que os habitantes do asilo dos "sem-razão" usavam a cidade. Apartados dela, fixados em seus devidos lugares, a razão científica fornecia o equilíbrio da urbe. Michel Foucault, no início da década de 1950, impressionou-se com o bloco mascarado. No comentário sobre o filme de Rene Féret, o filósofo afirma:

O filme de Rene Féret, em sua imensa beleza e rigor, me lembra, acima de tudo, aquelas festas de loucos, como existiam em certos hospitais da Alemanha e da Suíça não muitos anos atrás: no dia do carnaval, os loucos se fantasiavam e faziam um desfile de máscaras pelas ruas: curiosidade incomodada, um pouco assustada dos espectadores: o único dia em que se permitia aos loucos sair era para os outros rirem e se fazerem de loucos (Foucault apud Bert \& Verdeaux, 2017, p. 27).

\footnotetext{
${ }^{1}$ Jean-François Bert, no ensaio O bloco dos sem razão (Bert \& Verdeaux, 2017), afirma que, "Ao presenciar, nos anos 1950, o carnaval de pacientes de um asilo suíço, o jovem Michel Foucault encontrou uma das chaves para sua História da loucura [. . .]. Geralmente desprezado pelos especialistas em Foucault, esse início dos anos 1950 foi, apesar de tudo, determinante" (Bert \& Verdeaux, 2017, pp. 24-27).
} 
$\mathrm{Na}$ terça-feira gorda, a "curiosidade incomodada, um pouco assustada" justificava-se no desconforto provocado pelos carnavalescos irreconhecíveis, porém o riso amenizava a tensão do não reconhecimento. No último dia do carnaval, muros e portões tornavam-se ineficientes na delimitação das fronteiras do local de partida dos foliōes, mas nem sempre fracassavam; o bloco do hospício, reconhecido pelos espectadores, diluía o desconforto iminente de um rosto embaçado, de um corpo indefinido, do ninguém, do estorvo do estranho. As calçadas de Munsterlingen acolhiam paradoxos do anonimato a dissolver fronteiras inquebrantáveis da paisagem rotineira. $\mathrm{O}$ asilo dos "semrazão" ultrapassava os limites arquitetônicos, misturando-se ao olhar assustado de certos espectadores. $\mathrm{O}$ incômodo propiciado pela imprecisão de localizar os loucos, assim como a segurança doada pela tradição do carnaval manicomial, materializava-se nos guizos, orelhas de burro, nas máscaras satíricas da cidade suíça. Fora do cárcere manicomial, a identidade de seus habitantes perdia a clareza de seus contornos. Nas ruas, experimentavam burlar, à semelhança dos carnavais da Idade Média, poderes que os tornavam fracos e alheios ao mundo ao redor. Bakhtin, no estudo sobre os carnavais populares medievais, assinala a transgressão momesca:

O princípio cômico que preside aos ritos do carnaval liberta-os totalmente de qualquer dogmatismo religioso ou eclesiástico, do misticismo, da piedade, e eles são além disso completamente desprovidos de caráter mágico ou encantatório (não pedem nem exigem nada). Ainda mais, certas formas carnavalescas são uma verdadeira paródia do culto religioso. Todas essas formas são decididamente exteriores à Igreja e à religião. Elas pertencem à esfera particular da vida cotidiana (Bakhtin, 1993, p. 6).

Quando muros e grades do manicômio malogravam na função de identificar seus habitantes, os mascarados, por algumas horas, invertiam valores, parodiavam fatos políticos da atualidade, zombavam dos poderosos na recusa do destino asilar a eles delegado ${ }^{2}$. Na terça-feira, as ruas de Munsterlingen eram ocupadas pela transgressão momesca. No último dia da folia, pacientes saíam das amarras identitárias, escapavam do torpor do dia a dia, exibindo, com seus adornos, críticas irônicas à cultura e à política. Faziam, porém, rir aos espectadores quando fracassava o poder da máscara a recusar a finitude e a clareza de um rosto, ou a determinação de um destino. Nas ruas experimentavam ser ninguém, por meio da multiplicidade de sentidos dos personagens que representavam com ironia. Nas calçadas da urbe, ensaiava-se a afirmação de outra modalidade de existência fora dos ditames da lógica manicomial e, simultaneamente, a sua reprodução.

\footnotetext{
${ }^{2}$ Segundo Bert, a respeito da irreverência da crítica política do bloco, "O travestimento, assim como a zombaria e a derrisão, parece aceitos, em particular em se tratando da atualidade política. Vemos o martelo e a foice da URSS espetados na lapela do paletó do boneco de palha; uma tabuleta faz referência direta à Conferência de Berlim, que supostamente resolveria a Guerra Fria. O carnaval é um dos lugares da sátira e da crítica, seja ela local ou, ao contrário, internacional” (Bert \& Verdeaux, 2017, p. 38).
} 
Brincando de ser algo como nada, reproduziam e recusavam o manicômio encarnado em seus corpos, quando a cidade se misturava aos risos e guizos de uma longa e conflitiva história da loucura. Foliões experienciavam anonimatos discrepantes, presentes nas imagens que modulavam o infinito e a finitude de um rosto. O infinito dos agenciamentos, dos inesperados acontecimentos, do ainda não, produzido por margens e contornos desenhados pela história avessa a conclusōes, por alteridades que desestabilizam e criam sentidos inauditos. $\mathrm{O}$ infinito, segundo Foucault, incansavelmente construído:

Os homens jamais deixaram de construir a si mesmos, quer dizer, de deslocar, continuamente, sua subjetividade, de se constituírem em uma série infinita e múltipla de subjetividades diferentes, que jamais terão fim e que jamais nos colocarão em face de alguma coisa que seria o homem. Os homens engajam-se perpetuamente em um processo que, construindo objetos, os desloca, ao mesmo tempo que os deforma, os transforma e os transfigura como sujeitos (Foucault, 2013, pp. 325-326).

Qual potência se afirmaria no infinito das margens de um rosto anônimo? Qual o poder de uma máscara?

Nas favelas do Rio de Janeiro, em revoltas urbanas, nos vários cantos e cárceres do Brasil, experiências similares se repetem sem os ornamentos e risos do carnaval suíço. Paradoxos do anonimato emergem do tenso campo do cotidiano urbano. Extermínios de corpos, e de sua força política, são operados junto à conversão desses corpos ao anonimato, reduzido à finitude das amarras de uma identidade, ou ao nada. A urbe é apaziguada à semelhança do rumor dos guizos que faziam rir aos espectadores do cortejo suíço. Atrás das máscaras das manifestações urbanas, nas periferias, no corpo marcado pela predestinação de um destino, um homogêneo coletivo apresenta-se como se, nas bordas de suas formas, inexistissem agonias e lutas incessantes. Loucos, negros, mulheres, travestis, entre outros, trariam, atrás das máscaras, o rosto que os encarcera na localização precisa de uma marca. Segundo Foucault, a essas vidas à margem seria negada a inutilidade do nome, o vazio transgressor do anonimato:

Trata-se, atualmente de saber como um indivíduo, um nome pode ser o suporte de um elemento ou grupo de elementos que, vindo se integrar na coerência dos discursos ou na rede infinita das formas, vem apagar ou, ao menos, tornar vazio e inútil esse nome, essa individualidade da qual ele traz, até um certo ponto, durante um certo tempo e para certos olhares, a marca. Temos que conquistar o anonimato, justificar-nos pela enorme presunção de nos tornarmos um dia, enfim, anônimos, um pouco como os clássicos tinham que se justificar pela enorme presunção de ter encontrado a verdade e ligar seu nome a ela (Foucault, 2005, pp. 73-74). 
Nos cantos dos infames, dos banidos da ordem, uma concepção peculiar de anonimato poderá recusar a marca de um nome, ou de uma revolta particular. $\mathrm{O}$ ninguém, o qualquer um, o indefinível afirma-se como modo estratégico de enfrentamento às abjetas ações da violência do Estado. $\mathrm{O}$ anonimato se desvencilha de ser carência, vulnerabilidade entranhada nos limites de um corpo. Ações corporificadas em leis, ou em atos miúdos do dia a dia, são inquiridas. Esquadrinham dores e lutas que não atravessam outros espaços. No anonimato proposto por Foucault, resiste-se ao recusar a clareza imaculada de qualquer pronome pessoal, do destino de um povo, da privatização de um afeto. $\mathrm{O}$ anonimato ganharia forma por meio de uma modalidade de experiência. Segundo Bordeleau (2018), à luz das reflexôes de Foucault:

A experiência do anonimato corresponde para Foucault a uma tentativa, incessantemente renovada que se expressa sobre diversos planos - do mais pessoal ou anedótico ao mais conceitual-, de desprender-se de si mesmo com o fim de pensar e perceber de outra maneira (p. 180).

O desprender-se de si não se atrelaria ao ato de uma vontade, ou de um desejo, e sim a um conceito peculiar de experiência. Experiência que se diferencia das qualidades universais do sujeito, do protagonismo da consciência, ou de qualquer dinâmica da subjetividade privatizada. Para Bordeleau, citando o filósofo francês, o desprender-se de si seria em uma arte de viver, operada em campo de forças, que "consiste em matar a psicologia e criar consigo mesmo e com o outro, individualidades, seres, relações que não têm nome. Caso alguém não possa fazer isto com sua própria vida, ela não merece ser vivida" (Foucault apud Bordeleau, 2018, pp. 18-19). Segundo Foucault, a experiência na qual a Psicologia seria inútil caracterizaria um processo de dessubjetivação:

A fenomenologia procura recobrar a significação da experiência cotidiana para reencontrar em que o sujeito que sou é efetivamente fundador, em suas funções transcendentais, dessa experiência e dessas significações. Em compensação, a experiência em Nietzsche, Blanchot, Bataille tem por função arrancar o sujeito de si próprio, de fazer com que não seja mais ele próprio ou que seja levado a seu aniquilamento ou à sua dissolução. É uma empreitada de dessubjetivação (Foucault, 2013, p. 291).

Empreitada arriscada, que requer a subtração de um si mesmo enclausurado em seus limites, assim como das agonias do existir apartadas dos paradoxos do mundo. Subtração produtora do vazio indutor da curiosidade por outras dores e alegrias que existiram, existem, ou estarão por vir. Empreitada perigosa, porque do nome, do corpo, da identidade como âncoras, ou leme, não terão nenhuma eficácia. A experiência como dessubjetivação permite a ocupação, sempre 
provisória, de um espaço impessoal, deixado vazio por experiências anteriormente ancoradas por sujeitos, "eus", coletivos transfigurados e desalojados após a arriscada empreitada, segundo Foucault, de aniquilamento. Para Bordeleau (2018), em tal ato, configura-se "uma certa ideia do comum e da sua produção [. . .] uma aposta-chave da resistência ao governo por individualização" (p. 31). Para o pesquisador do anônimo em Foucault, na produção do comum, encontra-se uma "experiência ofensiva de anonimato" (Bordeleau, 2018, p. 27), que interrompe as ofertas identitárias do mercado neoliberal, assim como a privatização da subjetividade, da qual o desprender-se de si seria um infortúnio. Ofensa de uma peculiar aposta ética.

Que modalidade de cidade faria emergir a tensão insolúvel provocada pelos paradoxos do anonimato? Qual o poder aniquilador de uma máscara?

\section{A CIDADE COMO CAMPO MINADO}

Assertivas que defendem a participação dos excluídos, dos invisíveis na cidade como artífices da história ganham relevância na atualidade. É contestada a história oficial protagonizada por personalidades ou por acontecimentos alheios ao dia a dia das ruas, de certas áreas da urbe. Para os historiadores do cotidiano, mulheres, negros, trabalhadores, loucos, infames de várias nuances, a opacidade dos seus atos é recusada; recusa que reivindica o protagonismo da invisibilidade turbulenta do cotidiano para a contestação radical da historiografia dos vencedores. Narrativas anônimas, gestos miúdos de gente sem glória, inquirem a história dos grandes feitos problematizando vitórias e fracassos. Das artes nos muros das ruas, aos movimentos sociais, às intervenções urbanas da arte e da política, o anonimato esquiva-se da imobilidade, do nada a dizer, da invisibilidade. Aposta metodológica vigorosa para ampliar, tornar mais complexa a capilaridade da violência do Estado, assim como as inesgotáveis formas de combatê-la. No entanto a visibilidade desses agentes da história, fundamentada na metodologia, ou ação política, que os incita a dizer algo sobre o mundo, não garantiria o poder de interromper o curso da história indiferente às mazelas cotidianas. A luz que oferta a nitidez de um rosto, e a voz liberada por esta luz, corre o risco de aniquilar a força intensiva do anonimato ${ }^{3}$. A experiência do "desprender-se de si" proposto por Michel Foucault fracassaria. A gente sem nome, os seres à margem inclusos como protagonistas políticos não estariam imunes da captura das amarras identitárias.

\footnotetext{
${ }^{3}$ Sobre a força intensiva do anonimato, Walty (2007), na análise do romance Eles eram muitos cavalos, de Luiz Ruffato, afirma: "É justamente por construir seu texto como uma montanha de coisas/pessoas aparentemente indistinguíveis, ou, de forma paradoxal, retirar essas pessoas/coisas da mistura em que se encontram que Ruffato faz do anonimato condição de resistência, possibilidade de alteridade" (p. 65).
} 
Nas cidades entendidas como um campo minado, à semelhança de um assentamento produzido pela conflitualidade da vida social, a inclusão, ou a heroicização do excluído, é posta em xeque. Percorrer esse campo minado requer tônus para se arriscar aos efeitos da implosão de categorias comumente utilizadas sobre o tema, assim como à desacomodação da consistência de ideários supostamente libertários. Trata-se de um percurso no qual a adjetivação do infame dará lugar à emergência de paradoxos que exponham a ambiguidade do anônimo. $\mathrm{O}$ anonimato é exposto como algo que difere ao rechaçado pela história oficial à espera de reconhecimento. $\mathrm{Na}$ cidade como campo minado, aberta à tensão insolúvel da conflitualidade do jogo de forças do campo social, a visibilidade do infame não necessariamente poderá inquirir o poder que os enfraquece e os extirpa.

Pretende-se, neste artigo, inspirados nas reflexões de Foucault, reafirmar a presença vigorosa dos infames como artífices na produção da história. $\mathrm{Na}$ contramão de uma heroicização do excluído, porém, propõe-se denotá-los como habitantes do anonimato "noturno", desvencilhado das presas da sujeição que os faz brilhar, dizer seu nome e realizar o seu destino:

Para que algo delas chegasse até nós, foi, porém, necessário que um feixe de luz, ao menos por um instante, as viesse iluminar. Luz essa que lhes vem do exterior. Aquilo que as arranca à noite em que elas poderiam, e talvez devessem sempre, ter ficado, é o encontro com o poder; sem este choque, é indubitável que nenhuma palavra teria ficado para lembrar o seu fugidio trajeto (Foucault, 1992, p. 97).

$\mathrm{Na}$ cidade, à semelhança de um campo minado, luz e a opacidade noturna, visibilidade e invisibilidade são modulações de modos de enfrentamentos. Nos embates do poder a clareza de um rosto que diz eu, ou nós, poderá ser esmaecida quando requerer para si a exclusividade de suas agruras, ou o protagonismo de incansáveis combates. Do esmaecimento, a luta ganha outros contornos. $\mathrm{Na}$ noite, "em que elas poderiam, e talvez devessem sempre, ter ficado", a intensidade do ainda não, da insurgência por vir, aguarda prováveis estranhamentos, transtornos que abram espaços para um vazio à espera de criação. Qual o poder de um mascarado anônimo?

A cidade como campo minado não seria exterior às instituições. A porosidade dos muros a faz presente como parceira da experiência do anônimo. No cenário de um anonimato ambíguo e paradoxal, Bert e Verdeaux (2017) fazem referência ao "status curioso" de Foucault, por ocasião de seu ingresso como estagiário nos hospícios no início da década de 1950. A qualidade ambígua e indefinida de seu campo de interaçôes será registrada pelo próprio filósofo no seguinte comentário: 
O chefe do serviço era muito gentil comigo e me dava total liberdade de ação. Ninguém, no entanto, se preocupava com o que eu deveria fazer: eu podia fazer qualquer coisa. Ocupava, na verdade, uma posição intermediária entre a equipe e os pacientes (Foucault apud Bert e Verdeaux, 2017, p. 29).

As situaçôes enfrentadas pelo jovem estagiário Foucault, que começava a tomar contato com as práticas psiquiátricas de seu tempo, vieram acompanhadas de um franco questionamento dos usos e abusos das instituiçôes asilares, cada vez mais dominadas pelo discurso médico, que, por sua vez, apoiava-se no vertiginoso avanço das terapias psicofarmacológicas e da neurocirurgia. Este Foucault "sem lugar", transitando por aqui e ali, como que à deriva de qualquer fixação clara de atribuições e sentidos, poderia gerar à primeira vista uma sensação de desamparo e confusão diante de uma estrutura hierárquica bem consolidada e minuciosamente organizada. No entanto, na experiência foucaultiana, abre-se espaço para outra coisa.

O status curioso constitui também uma forma de habitar a assepsia do hospital e de arriscar as frágeis certezas daquilo que se pensa e se faz. O filósofo sem lugar, e à margem, acaba construindo de forma "atópica”, um espaço exterior àquele dos lugares e atribuições consolidadas no jogo das práticas nas quais é convocado a intervir. Habitar esse lugar que, ao mesmo tempo, consegue ser interno e externo, estar dentro e fora, constitui um grande desafio. $\mathrm{O}$ anonimato do pensar, este que nos lança em um espaço incerto e arriscado, faz-se presente no colocar-se à prova em um campo minado, em que definições certeiras abrem espaço para experimentações que recusam os destinos inevitáveis ou as utopias de um mundo ideal. A cidade atravessava as paredes do hospício.

A trajetória de Foucault afirma a importância decisiva de "levar em conta as palavras esquecidas, acompanhar as coisas mais humildes e menosprezadas" (Bert \& Verdeaux, 2017, p. 44), recolhendo o rejeitado, o excluído e o infame, à imagem de um trapeiro ${ }^{4}$. Olhar para esse rejeito é condição fundamental para a crítica daquilo que somos, ou temos sido. Walty (2007), ao discorrer sobre o estatuto do anonimato na obra literária de Ruffato, diz que o lixo amontoado nas esquinas tem muito a dizer, fazendo desmanchar o status de um conhecimento do mundo que se pretende exaustivo e universal. Nesse sentido, as histórias pequenas e inconclusas, forjadas em meio aos amontoados de coisas e acontecimentos da vida de todo dia, podem produzir os desassossegos e os alertas necessários

\footnotetext{
${ }^{4} \mathrm{O}$ trapeiro inspira-se em Walter Benjamin, especificamente como alegoria presente em sua obra, no intuito de apresentar uma proposta metodológica. Benjamin, na análise da obra de Charles Baudelaire, cita o poeta francês e fornece pistas sobre uma metodologia: "Aqui temos um homem - ele tem de recolher na capital o lixo do dia que passou. Tudo que o que a cidade grande jogou fora, tudo que ela perdeu, tudo que desprezou, tudo o que destruiu, é reunido e registrado por ele [. . .] separa as coisas, faz uma seleção inteligente; procede como um avarento com seu tesouro" (Baudelaire apud Benjamin, 1989, p. 78).
} 
ao tempo presente. Essas histórias podem encarnar a face de um anonimato concebido como força intensiva, possibilidade radical de uma alteridade em face daquilo que nos assola. Contar e recontar essas histórias é tarefa necessária e urgente. Como as contar preservando seu teor libertário e transformador? Como não se deixar capturar pelo insistente torpor que as domestica, dá nome e as faz confessar suas verdades, impedindo que elas venham nos tocar e desestabilizar? E, mais: que histórias são essas?

Retornando ao estagiário sem nome ou lugar, Bert e Verdeaux (2017) falam dos efeitos que a visita ao carnaval dos loucos pode ter despertado em Foucault. Um deles seria a decisão de romper com uma dada maneira de fazer história e filosofia, propondo-se a tratar dos fenômenos sociais a partir de "casos", "com a finalidade de desatrelar seu discurso de toda sistematicidade doutrinal ou ideológica" (Bert \& Verdeaux, 2017, p. 44). A noção de caso também traz consigo o anonimato e sua constituição paradoxal. Não se trata, aqui, de pensar o caso como recurso para prognósticos definitivos ou como problemas cujas soluções seriam apresentadas de forma abstrata e imputável a todos e todas; soluções bem localizadas sob os arcabouços generalizantes das grandes "sistematicidades doutrinais" já citadas, que utilizam o "anônimo" ou o "sigilo" como confirmação de hipóteses pré-aprovadas no jogo das discursividades. Os "casos" assim considerados, "casos clínicos", como alguns costumam chamá-los, serviriam apenas para reforçar uma configuração de forças em que o anônimo é capturado por forças de conservação prontas a dar-lhes um nome e reduzirlhes à sua suposta essência. Talvez não seja isto que interesse a Foucault. Tratar a noção de caso de outra maneira, abrindo espaço também para outra forma de anonimato, seria considerá-lo como singularidade irredutível às chaves de apropriação e classificação doutrinais. Pensar por casos, singularidades ou situações, como bem asseveram Bert e Verdeaux (2017), implica reduzir a escala das análises, atentando-se ao ínfimo, ao pequeno e supostamente "inútil”, para então melhor desmontar as complexas e múltiplas linhas históricas que sustentam um mesmo acontecimento.

Pensar "por casos" é o que representa um verdadeiro desafio para Foucault. Além de transgredir as abordagens disciplinares clássicas, o caso é o que lhe permitirá, além de concentrar-se no vivido, produzir complexidade e considerar impossível uma explicação monocausal de um acontecimento (Bert \& Verdeaux, 2017, p. 50).

O caso dificultaria toda tentativa de generalização, liberando o caminho para forças que colocam o anônimo não como lugar da representação das certezas estanques, mas num campo de tensões, em que corremos o risco de perecer e nos tornarmos outra coisa. Em outros termos, para fortalecer o anônimo 
como força libertária e disruptiva, é preciso tratar o "caso" como singularidade irredutível à norma. À luz da reflexão de Foucault (1992), no ensaio A vida dos homens infames, singularidade produzida por uma força "noturna" do ainda não, do inclassificável, do por vir, do inominável que aturde a lassidão de um pensamento, ou de um corpo. $\mathrm{O}$ caso, visto como singularidade, faz-se presente sem ser assimilado às prescrições generalizantes, e, por isso mesmo, constitui caminho para outros modos do pensar. No entanto cabe ainda nos perguntar como fazer com que esses "casos", quase sempre recolhidos em tons fragmentários, preservem e intensifiquem as forças de um anonimato concebido como abertura para o tempo e para outras formas de se contar a história 5 . Como pensar formas de transmissibilidade do vivido, de maneira a evitar as armadilhas dos sentidos já dados, que retiram do anônimo sua força intensiva e questionadora?

Talvez uma dessas maneiras seria experimentar certa forma de escrita. Walty (2007), ao discorrer sobre a posição do anonimato na obra do escritor Ruffato, destaca a importância de uma escrita "deslocada" e "contaminada". Ruffato (2017), em seu livro Eles eram muitos cavalos, narra cenas do cotidiano da grande cidade, reunindo diferentes estilos de narração, de cartas a poemas, passando por listas, orações, cardápios, etc., expondo o teor heterogêneo das coisas que nos constituem, impedindo ou ao menos obstando ao ímpeto classificatório do leitor de primeira viagem.

Escrita deslocada, pois reúne elementos numerosos e, à primeira vista, díspares, que fazem parte do cotidiano urbano, trazendo à tona os paradoxos desse mesmo cotidiano. Ruffato (2017) faz isso na reunião, no mesmo livro, de salmos bíblicos e listas de livros, ou ainda na descrição detalhada de conversas telefônicas bem como na construção de prosas, nas quais, os encontros na cidade não se dão sem alguma forma de choque ou conflito insolúvel. Escrita contaminada, pois dá voz e contorno às figuras do resto e do lixo, daquilo que é rejeitado pelo imperativo da ordem e da limpeza, fazendo emergir das cenas descritas a tensão de elementos materiais e históricos divergentes, justamente o que deveria permanecer escondido sob a névoa das identidades produzidas no jogo capitalista.

O empesteado ar de janelas fechadas, vidros suados no soalho, esparramados, papéis de bala, de bolacha, guardanapos, sacolas, palitos de picolé, copos descartáveis, garrafas plásticas,

\footnotetext{
${ }^{5}$ Trata-se de uma "história a contrapelo", tal como propõe Benjamin (1987), ao elaborar suas teses sobre o conceito da história, fazendo a crítica de um certo modo de transmiti-la a partir do ponto de vista dos vencedores, reiterando a produção e a reprodução da barbárie que ainda persiste na cultura e em suas formas de transmissibilidade. Fazer uma história a contrapelo seria abrir espaço para aquilo que não foi dito e que ficou soterrado sob os escombros de uma racionalidade ciosa do "progresso", como linearidade necessária e ininterrupta. Escovar a contrapelo implica o exercício de se colocar à procura das vozes caladas antes do tempo, dos corpos aniquilados sob as motivaçôes espúrias dos projetos de poder que orientaram e ainda orientam os caminhos tomados por certas práticas e pensamentos contemporâneos.
} 
farelo de biscoito de polvilho, de pão, de broa, farinha, restos de comida, pé de sapatinho de crochê azul-menino, noitedia (Ruffato, 2017, p. 18).

Ainda segundo Walty (2007), Ruffato embaralha, desloca e contamina as vozes de diferentes seguimentos sociais:

Os motoristas de carros caros, donos do Rolex, das roupas e dos perfumes de grife, e os passageiros dos ônibus ou os simples empregados; o barulho da música ou das balas de revólver "tum-tum-tum-tum-tum-tum-tum-tum" [. . .]. Percebe-se um movimento de interpenetração de grupos sociais diversos, sem possibilidade de se detectarem os agentes ou pacientes da violência social: os ricos que investem na bolsa, seus filhos, os decoradores, os traficantes, os delegados, os donos de boate, as garotas de programa, os leões de chácara (Walty, 2007, p. 31).

Essa forma de escrita não deve servir como "modelo" a ser reproduzido, pois não se trata de "descobrir" uma forma ideal de transmitir as tensões e paradoxos dos cenários da vida cotidiana. No entanto sua maior contribuição talvez seja o fato de que ela não fala pelo outro e muito menos o assimila em figuras prontas e reificadas. Ela pode, assim, constituir uma forma de experimentação ética, em movimento, diante da complexidade de elementos em que se situa.

Mobilidade e inacabamento são partes constitutivas dessa experimentação. Aqui as pessoas e as coisas não carregam um nome fixo, não carregam sequer um nome. Muito além de interpretar ou representar um mundo dado, essa escrita ocupa-se em "mostrar" as tensôes vivas, anônimas e indistinguíveis, daquilo que fazemos e temos sido em meio às artérias da cidade contemporânea.

Ruffato (2017) situa suas histórias na rua, no trânsito, na calçada, nos apartamentos, escolas, no movimento incessante e torrencial da grande metrópole. Suas histórias passam por nós com pressa, velozes como os carros ou pedestres na cidade acelerada. Elas deixam, em seus rastros, em seus restos, as figuras inacabadas de outras formas de habitar essas mesmas ruas, atuando como picaretas a rachar o asfalto duro, ou compactas verdades.

Abrindo o asfalto, abrindo a cidade, essas histórias tensionam os modos anquilosados e estáticos de experimentá-la. Sua força reside nos elementos misturados sacados de suas configuraçōes usuais, na "montanha de coisas/pessoas aparentemente indistinguíveis" (Walty, 2007, p. 39) e que podem reforçar uma condição de anonimato como luta de transformação do presente, em que os combates de uma cidade não se deixam capturar pela tranquilidade das utopias próximas ou distantes. 
A cidade, nesse sentido, é o campo das contaminações e deslocamentos fortuitos, em que as lutas se fazem à revelia dos esforços de classificação que ordenam e apaziguam. Concebida como campo minado, não há como nela caminhar sem riscos que abalam o nosso próprio modo de viver e agir. Ela exige de nós o exercício de uma atenção conectada ao fortuito, ao intempestivo ${ }^{6}$ dos encontros pequenos que ainda insistem, rompendo a malha fina da privacidade $\mathrm{e}$ do isolamento de um "eu" ou de um nome próprio, estremecendo-os, liberando outras formas de contar as histórias que nos constituem.

O "status curioso" do estagiário sem nome também pode favorecer essa experimentação. Caminhando sem destino certo pelos corredores do hospício, onde será que ele vai parar?

O desfile de carnaval dos loucos pode deixar o hospital e ganhar a cidade. Contaminado pelo cantarolar e pelos tambores que batem, o estagiário/filósofo sem nome e também mascarado se deixa levar ${ }^{7}$. Perigosa e arriscada a cidade do anônimo o espera. Fantasias e máscaras coloridas, feitas também de improviso, com rejeitos ou papel machê, têm algo a dizer e mostrar. Qual o poder de uma máscara?

\section{MÁSCARAS}

Oculto pela máscara, o indivíduo dilui-se na coletividade, na sua memória e nos seus sonhos para dali extrair novos argumentos e razões. Converte-se em deus, no seu próprio antepassado, em animal mítico, em herói ou em fantasia, para regressar a si mesmo, negado e marcado, escondido pelo duplo papel que lhe revela a cena de sua cultura. A máscara permite ao homem representar a sua condição de ser e não ser. Permite a ele recordar a temível verdade do simulacro, o recurso da ficção que deve esconder para revelar. Permite o inquietante paradoxo da comédia humana, de toda a cultura que expressa o que diz e o que silencia (Escobar, 1992, p. 52).

O uso de máscaras recebeu nova atenção após as manifestações sociais de junho de 2013, no Brasil; nas ruas, foi uma prática recorrente nas ações dos grupos militantes libertários. Criminalizada por lei estadual no Rio de Janeiro (Lei Estadual no 6.528, 2013), foi identificada nos discursos hegemônicos como associada aos confrontos com as forças de segurança pública e atos de vandalismo. A proibição da simulação do rosto no espaço público vincula-se a conteúdos

\footnotetext{
${ }^{6}$ Walty (2007), ao abordar o anonimato como experimentação ética e política, fala de uma força intempestiva da perda de identidade. Para pensar o anonimato como possibilidade de diferenciação do já dado, de um sistema constituído, seria preciso também guardar uma conexão com o acaso, distanciando o exercício do anonimato (portanto a perda de uma identidade) de uma concepção voluntarista ou intencional.

${ }^{7}$ Sabemos que a visita de Foucault a Munsterlingen, descrita por Bert e Verdeaux (2017) e que dá início a este artigo, dá-se tempos após sua experiência de estágio em instituiçôes asilares. Mesmo assim, deslocamos essas temporalidades, no intuito de intensificar a força de uma experiência sem nome, decisiva para os caminhos do pensamento contemporâneo.
} 
identitários, sejam culturais (formadores de identidade de grupo) ou políticos como a própria noção de cidadania, engendrando um dispositivo de poder em busca da anulação dos perigos que os corpos sem rosto comportam ou traduzem. Resistências de coletivos que insistem em desafiar tal imposição, construindo performances inspiradas na provável intensidade do anonimato, assumem a luta contra a institucionalização de uma política na qual as máscaras apenas sabotam a visibilidade de um nome ou de um rosto.

Pano na cara e máscaras: camuflagem para ativistas engajados em práticas ilegais, indumentária padrão dos "vândalos" e subversivos. Essas alegorias, compartilhadas publicamente durante análises sobre as ações de confronto, retratam a máscara como protetora de identidades contra a investigação posterior da polícia por meio de vídeos ou a perseguição por outras instituições sociais, como família, trabalho e escola, daqueles que se engajam em manifestações.

A perseguição aos denominados radicais e repressão de práticas desviantes e marginais são comuns às instituições tradicionais ${ }^{8}$. As "Marchas da Maconha" chamadas como um baile de máscaras e o aspecto carnavalesco das paradas LGBT por todo Brasil se apropriaram, no início, do uso das fantasias com um caráter prático: garantia do direito de se manifestar politicamente sem se colocar necessariamente em uma situação de fragilidade e exposição social, diante de instituições conservadoras como família e trabalho. A ambiguidade do anonimato, assim como no bloco carnavalesco do manicômio suíço, faz-se presente nos movimentos sociais em que os paradoxos da cidade como campo minado afirmam-se com suas tensões insolúveis.

Entre o fenômeno social dos protestos e o uso da proteção constitucional que veda a manifestação anônima do pensamento, constata-se o uso de leis como dispositivos do controle estatal, a exemplo da proibição da tática do black bloc. Vale destacar que tal tática envolve não apenas os ataques diretos a símbolos da globalização do capitalismo, mas também a desobediência civil e a resistência às forças de dispersão policial dos protestos, que requer diretamente o uso de máscaras (intensificado desde 2013 e objeto de muitas análises políticas). Caricaturados pelos enunciados midiáticos, adeptos da tática black bloc são postos em discussão apenas pelas representações a que interessam a essas instituições, em geral associadas à manutenção da ordem e do poder. Sobre essa construção midiática de fenômenos sociais, Coimbra (2001) afirma:

\footnotetext{
${ }^{8} \mathrm{Na}$ Assembleia Legislativa do Rio de Janeiro, uma expressão das reaçōes do Estado contra as insurgências de junho de 2013 desdobra-se na aprovação da Lei Estadual no 6.528, de 11 de setembro de 2013, conhecida como "Lei da proibição das máscaras", supostamente baseando-se no texto da própria Constituição, que fala em "anonimato", uma única vez, no artigo 5º inciso IV: "É livre a manifestação do pensamento, sendo vedado o anonimato".
} 
O "rosto" midiático que unilateralmente simplifica, homogeneíza e, ao mesmo tempo que fragiliza, espetaculariza certos acontecimentos, tornando-os "fora do comum", dramáticos e emocionantes: só assim serão dignos de se tornar notícias. Este "rosto" que está criando cotidianamente outros "rostos", como se fossem identidades fixas e cristalizadas, nos leva, de um modo geral, a tomar posições passivas e acomodadas, pois nos defrontamos - e é isso que nos querem fazer acreditar - com obstáculos considerados intransponíveis, porquanto produzidos como blocos petrificados, estáticos; seriam, portanto, impossíveis de transpor/ mudar (p. 249).

Máscaras nas manifestações urbanas na atualidade recusam o "rosto midiático que simplifica, homogeneíza". Diferentes apelos, palavras de ordem ocupam as calçadas e deixam atônitos os que almejam reencontrar a rebeldia do outrora. A face não se deixa ver, e nessa recusa, a cidade é solidária quando se exime de ser apenas palco, cenário, pavimento para circulação. Muitos exibem a face. Alguns, conectados ao que a urbe oferece como experimentação, escondem-na e revelam um inaudito e infinito rosto. Nele, o anonimato torna-se uma "noturna” posição de ataque:

Numa manifestação, um sindicalista arranca a máscara de um anônimo que acaba de quebrar uma vitrine: "Assume o que você faz, ao invés de se esconder". Estar visível é estar a descoberto, ou seja, antes de tudo, vulnerável. Quando esquerdas de todos os países não param de "dar visibilidade" a sua causa - seja a dos mendigos, a das mulheres ou a dos imigrantes ilegais - na esperança de que ela seja levada em consideração, fazem exatamente o contrário do que seria necessário fazer. Não nos tornarmos visíveis, mas virar para o nosso lado o anonimato a que fomos relegados e, pela conspiração, pela ação noturna ou mascarado, fazer dele uma inatingível posição de ataque (Comitê Invisível, 2013, pp. 132133).

Mascarados do hospício suíço de Munsterlingen, das manifestações urbanas das diferentes cidades do mundo, talvez tenham, junto às suas agonias e revoltas, uma alegria impertinente dos carnavais medievais doada pelas máscaras. Oferta que recusa um rosto, um nome, a exclusividade de agruras e sujeições como aposta ética. Nos carnavais medievais, encontra-se, também, a combativa experiência do anônimo:

A máscara traduz a alegria das alternâncias [. . . ] a alegre negação da identidade e do sentido único, a negação da coincidência estúpida consigo mesmo; a máscara é a expressão das transferências, das metamorfoses, das violaçôes das fronteiras naturais, da ridicularização; a máscara encarna o princípio de jogo da vida (Bakhtin, 1993, p. 35).

Para os modos fascistas de existir, operados pelo Estado, ou por atos miúdos do cotidiano, atrás das máscaras residiria medo e insegurança. A impertinência de uma alegria anônima dos carnavais medievais não é sentida. $\mathrm{O}$ fascismo não admite a opacidade de uma face ou o contágio propiciado por um coletivo feito 
por heterogêneas matérias e afetos. Repele com energia a "negação da coincidência estúpida consigo mesmo". Perder o rosto, segundo Foucault, ensejaria ouvir "o estrondo de uma batalha" . O estrondo que mistura inúmeras vozes de diferentes tempos e espaços, gritos, gemidos, silêncios, palavras de ordem, pausas para respirar, gargalhadas, suspiros que precedem a morte. $\mathrm{O}$ estrondo de embates incansáveis, passíveis de audição quando uma aposta ética se faz presente.

\footnotetext{
${ }^{9}$ Na obra Vigiar e punir, Foucault (2004) utiliza a expressão "ronco surdo da batalha" (p. 291), optamos pela tradução utilizada por Bordeleau em espanhol: "El estruendo de la batalha" (Bordeleau, 2018, p. 23).
} 


\section{REFERENCIAS}

Bakhtin, M. (1993). A cultura popular na Idade Média e no Renascimento: o contexto de François Rabelais. São Paulo: Hucitec.

Benjamin, W. (1987). Magia e técnica, arte e política: ensaios sobre literatura e história da cultura. São Paulo: Brasiliense. (Obras Escolhidas, 1).

Benjamin, W. (1989). Charles Baudelaire: um lírico no auge do capitalismo. São Paulo: Brasiliense. (Obras Escolhidas, 3).

Bert, J-F., \& Verdeaux, J. (2017). O bloco dos sem razão. A. Telles (Trad.). Serrote, 26.

Bordeleau, E. (2018). Foucault anonimato. Buenos Aires: Cactus.

Coimbra, C. M. B. (2001). Operação Rio: o mito das classes perigosas. Rio de Janeiro: Oficina do Autor.

Comitê Invisível. (2013). A insurreição que vem. Santos: Ediçōes Baratas.

Escobar, T. (1992). Textos varios sobre cultura, transición y modernidad. Asunción: Agencia Española de Cooperación Internacional, Centro Cultural de España Juan de Salazar.

Foucault, M. (1992). A vida dos homens infames. In A. F. Cascais, \& M. Foucoult. O que é um autor? (pp. 89-128). Lisboa: Passagens.

Foucault, M. (2004). Vigiar e punir: história da violência nas prisões. (29a ed.). Petrópolis: Vozes.

Foucault, M. (2005). Sobre as maneiras de escrever a história. In M. Foucoult. Ditos \& escritos: arqueologia das ciências e história dos sistemas de pensamento. (Vol. 2, pp. 62-77). Rio de Janeiro: Forense Universitária.

Foucault, M. (2013). Conversa com Michel Foucault. In M. Foucoult. Ditos \& escritos: repensar a política. (Vol. 6, pp. 289-347). Rio de Janeiro: Forense Universitária.

Lei Estadual no 6.528, de 11 de setembro de 2013. (2013, 11 setembro). Regula menta o artigo 23 da Constituição do Estado. Rio de Janeiro: Assembleia Legislativa do Estado do Rio de Janeiro. Recuperado a partir de http://alerjln1.alerj.rj. gov.br/contlei.nsf/4734bd1980be7a2003256b2a0061e644/95394833846e60a583257be5005ec84a?OpenDocument 
Ruffato, L. (2017). Eles eram muitos cavalos. São Paulo: Boitempo.

Walty, I. (2007, dezembro). Anonimato e resistência em "Eles eram muitos cavalos", de Luiz Ruffato. O Eixo e a Roda: Revista de Literatura Brasileira, 15, 27-41. Recuperado a partir de http://www.periodicos.letras.ufmg.br/index. php/o_eixo_ea_roda/article/view/3260 